\title{
POVEZANOST IZVRŠNIH FUNKCIJA I JEZIKA U ODRASLOJ DOBI*
}

\author{
Paula Krilčić \\ paula.krilcic@gmail.com \\ Sanja Šimleša \\ Odsjek za logopediju \\ Edukacijsko-rehabilitacijski fakultet Sveučilišta u Zagrebu \\ Borongajska cesta 83f, 10000 Zagreb \\ ssimlesa@erf.hr \\ Marina Olujić \\ Odsjek za logopediju \\ Edukacijsko-rehabilitacijski fakultet Sveučilišta u Zagrebu \\ Borongajska cesta 83f, 10000 Zagreb \\ marina.olujic@erf.hr \\ Jelena Kuvač Kraljević \\ Odsjek za logopediju \\ Edukacijsko-rehabilitacijski fakultet Sveučilišta u Zagrebu \\ Borongajska cesta 83f, 10000 Zagreb \\ jkuvac@erf.hr
}

\begin{abstract}
Sažetak
Brojna istraživanja upućuju na povezanost izvršnih funkcija i jezika. Ipak, zbog složenosti izvršnih funkcija, teškoća u njihovu definiranju i ispitivanju, točna priroda te veze još uvijek nije poznata. Većina dosadašnjih istraživanja izvršnih funkcija temelji se na dječjem jezičnom razvoju ili jezičnom razvoju kod specifičnih populacija. S obzirom na to da su i jezik i izvršne funkcije s obzirom na dob osjetljivi konstrukti, za spoznaje o dinamici njihova odnosa nužno je istraživanja proširiti i na odraslu dob. U skladu s time, cilj je ovog istraživanja bio ispitati povezanost pojedinih sastavnica izvršnih funkcija s jezičnim razumijevanjem u odrasloj dobi. Sudionici su bili odrasle osobe $(\mathrm{N}=30)$ u dobi između 21 i 37 godina. Izvršne funkcije prostornog radnog pam-
\end{abstract}

* Ovo ispitivanje provedeno je uz financijsku i tehničku podršku projekta Jezična obrada u odraslih govornika (HRZZ-UIP-11-2013-2421) Hrvatske zaklade za znanost. 
ćenja, prostornog planiranja, kognitivne fleksibilnosti i kognitivne inhibicije ispitane su CANTAB baterijom testova, a verbalno radno pamćenje ispitano je podljestvicom Pamćenje raspona brojeva WAIS-III testa. Jezične sposobnosti ispitane su Peabody slikovnim testom rječnika (PPVT-III-HR) i Testom razumijevanja gramatike (TROG2:HR). Rezultati regresijske analize pokazali su doprinos izvršnih funkcija u razumijevanju složenih, ali ne i jednostavnih rečenica, niti riječi. Dobiveni rezultati mogli bi značiti da je potreba za izvršnim funkcijama tijekom jezične obrade u odrasloj dobi ograničena na razumijevanje složenijih sintaktičkih struktura koje predstavljaju veće opterećenje za obradu. Takvi rezultati u skladu su s rezultatima sličnih stranih istraživanja, no za donošenje konačnih zaključaka potrebno je uključiti ispitanike starijih dobnih skupina i varirati veći broj struktura različite razine sintaktičke složenosti.

Ključne riječi: izvršne funkcije, jezik, receptivni rječnik, razumijevanje rečenica, odrasla dob

\section{UVOD}

Izvršne funkcije obuhvaćaju širok i raznolik raspon kognitivnih procesa koji služe prema cilju usmjerenom ponašanju, a osobito su važne u novim i zahtjevnim zadatcima i situacijama (Chan, Shumb, Toulopoulou i Chen, 2008). Odnose se na kognitivne procese potrebne za usmjeravanje i održavanje pažnje onda kada automatsko, instinktivno ili intuitivno procesiranje nije dostatno ili moguće (Burgess i Simons 2005; Espy 2004). Od niza sastavnica izvršnih funkcija koje se navode u literaturi, najčešće spominjane i ispitivane su kognitivna inhibicija, radno pamćenje i kognitivna fleksibilnost (Friedman, Miyake, Young, DeFries, Corley i Hewitt, 2008; Huizinga, Dolan i van der Molen, 2006; Miyake, Friedman, Emerson, Witzki, Howerter i Wager, 2000; Xu, Han, Sabbagh, Wang, Ren i Li, 2013). Navedene tri sastavnice čine niže razine obrade, a zajedno tvore složene komponente izvršnih funkcija, primjerice, prostorno planiranje (Xu i sur., 2013).

Sastavnice izvršnih funkcija podupiru i različite aspekte jezika, od razumijevanja do proizvodnje (Ye i Zhou, 2009). Za razumijevanje jezika, odnosno obradu rečenica, potrebno je integrirati različite izvore informacija (Vuong i Martin, 2015). Informacije o vršiteljima i trpiteljima radnje kao i o samoj radnji dohvaćaju se putem semantike, a odnosi među njima putem morfosintakse (Vuong i Martin, 2015). $\mathrm{S}$ obzirom na to da je sve te informacije $\mathrm{u}$ govornom jeziku potrebno prikupiti na temelju prolaznog akustičkog signala, pretpostavlja se da je za njihovu integraciju i tumačenje potrebno uključivanje izvršnih funkcija (Vuong i Martin, 2015; Gathercole, 2007). Stoga pojedini autori (Ye i Zhou, 2009) jezične procese i izvršne funkcije opisuju kao mrežu, odnosno kao međusobno isprepletene, a ne izolirane funkcije na neuralnoj razini. Isti autori smatraju kako tijekom jezične obrade izvršne funkcije djeluju tako da pri jezičnoj proizvodnji odabiru prave riječi potiskujući alternativne te da pri jezičnom razumijevanju odabiru najvjerojatniju interpretaciju složenijih rečenica. 
Navedena uloga izvršnih funkcija posebno je istaknuta tijekom razdoblja jezičnog razvoja (Kapa, 2013). Primjerice, empirijski podatci upućuju na prediktivnu vrijednost izvršnih funkcija za razvoj rječnika u predškolskoj dobi (Weiland, Barata i Yoshikawa, 2014), radno pamćenje povezano je s usvajanjem svih jezičnih sastavnica u razvoju prvog jezika (Fox, Berry i Freeman, 2014), a kognitivna inhibicija i fleksibilnost te prostorno planiranje značajni su prediktori jezičnog razumijevanja u dobi od 4 godine (Šimleša, 2013). Ta povezanost nastavlja se i tijekom nižih razreda osnovne škole (Gooch, Thompson, Nash, Snowling i Hulme, 2016). Razvoj različitih sastavnica izvršnih funkcija traje sve do adolescencije (Xu i sur., 2013), a prema nekima čak i do razdoblja rane odrasle dobi (Veroude, Jolles, Croiset i Krabbendam, 2013), dok u starosti njihovo opadanje počinje prije nego opadanje ostalih kognitivnih funkcija (Jurado i Rosselli, 2007).

S obzirom da se izvršne funkcije mijenjaju s dobi, i način međudjelovanja između izvršnih funkcija i jezika je promjenjiv s obzirom na dob (Kapa, 2013). Ipak, istraživanja tog odnosa tijekom odrasle dobi su rijetka, a rezultati često oprečni. Radno pamćenje jedna je od češće istraživanih izvršnih funkcija u odrasloj dobi, no njegova uloga u jezičnoj obradi još uvijek nije razjašnjena. Primjerice, i dok je prema nekim istraživanjima neintaktno radno pamćenje jedan od glavnih uzroka teškoća u rečeničnom razumijevanju (Harley, 2001), drugi, pak, opovrgavaju tako visoku, pa čak i bilo kakvu povezanost (Gathercole, 2007; Martin, Vuong i Crowther, 2007). Slično se događa i s ostalim izvršnim funkcijama. Dok su se u pojedinim istraživanjima značajno povezanima s rečeničnom obradom pokazale i kognitivna fleksibilnost i kognitivna inhibicija (Park, 2015; Vuong i Martin, 2015), u drugima se povezanost pronalazi samo s kognitivnom inhibicijom (Yoon, Campanelli, Goral, Marton, Eichorn i Obler, 2015). Jedno od objašnjenja ovakvih oprečnih rezultata odnosa jezičnog razumijevanja i izvršnih funkcija jest to da ta povezanost postoji tek u obradi duljih i složenijih rečenica (Van Gompel i Pickering, 2007) koje postavljaju veće zahtjeve na mehanizme rečenične obrade i zbog čega dolazi do izraženije potrebe za uključivanjem izvršnih funkcija (BornkesselSchlesewsky i Friederici, 2007; Novais-Santos, Gee, Shah, Troiani, Work i Grossman, 2007). Stoga, postoji potreba za dodatnim istraživanjem odnosa izvršnih funkcija i jezika u odrasloj dobi.

U skladu s time, cilj je ovog istraživanja utvrditi povezanost pojedinih sastavnica izvršnih funkcija s jezičnom obradom na razini razumijevanja. Preciznije, u središtu je ovog rada definirati povezanost između izvršnih funkcija (verbalnog radnog pamćenja, prostornog radnog pamćenja, prostornog planiranja, kognitivne fleksibilnosti i kognitivne inhibicije) i razumijevanja i to na razini riječi i na razini rečenica (jednostavnih i složenih). Na temelju podataka i nalaza dosadašnjih istraživanja, ne očekuje se doprinos izvršnih funkcija u razumijevanju riječi i jednostavnih sintaktičkih struktura. Međutim, očekuje se doprinos izvršnih funkcija u razumijevanju složenih rečenica odnosno očekuje se da će postignuća na varijablama izvršnih funkcija biti prediktivna za razumijevanje tih sintaktičkih struktura. 


\section{METODOLOGIJA}

\section{Sudionici istraživanja}

U istraživanju je sudjelovalo 30 osoba, od čega podjednako muškaraca i žena, dobi od 21 do 37 godina. Sudionici istraživanja su osobe urednog neurološkog i psihičkog statusa, urednog vida i sluha te uredne inteligencije, testirane Ravenovim progresivnim matricama (Raven, 1995). Neurološki i psihički status, kao i status vida i sluha utvrđeni su putem osobnog usmenog izvještavanja sudionika. Zbog prethodno dijagnosticirane depresije rezultati jedne sudionice su izostavljeni iz daljnje analize.

Osnovni podaci o sudionicima istraživanja nalaze se u Tablici 1 .

Tablica 1. Obilježja sudionika istraživanja

\begin{tabular}{llc}
\hline Broj ispitanika & $\mathrm{N}$ & 30 \\
\hline Spol & $\mathrm{M}$ & 15 \\
& $\breve{Z}$ & 15 \\
\hline Kronološka dob & $\mathrm{M}$ & 28,11 \\
& $\mathrm{MIN}$ & 21,05 \\
& $\mathrm{MAX}$ & 36,11 \\
& $\mathrm{SD}$ & 5,70 \\
\hline Obrazovanje & OSS/SSS & 3 \\
& VŠS/VSS & 26 \\
& Magisterij/doktorat & 1 \\
\hline
\end{tabular}

Mjerni instrumenti

\section{a) Testovi izvršnih funkcija}

Za ispitivanje izvršnih funkcija upotrijebljeni su baterija testova CANTAB (Cambridge Neuropsychological Test Automated Battery - CANTAB; Cambridge Cognition) te zadatak za pamćenje brojeva unaprijed i unatrag iz WAIS-III (Wechsler, 1997). Verbalno radno pamćenje mjereno je kao najdulji raspon brojeva unaprijed i unatrag koji ispitanik može upamtiti. Pamćenje brojeva unaprijed zahtijeva kratko zadržavanje i ponavljanje verbalnog materijala, čime se aktivira fonološka petlja, dok zadatak pamćenja brojeva unatrag zahtijeva, uz zadržavanje, i manipulaciju verbalnim materijalom te je stoga potrebna i veća aktivnost središnjeg izvršitelja, dok fonološka petlja zadržava informacije. CANTAB je baterija implementirana kao aplikacija na uređaju s ekranom osjetljivim na dodir. Sastoji se od 24 


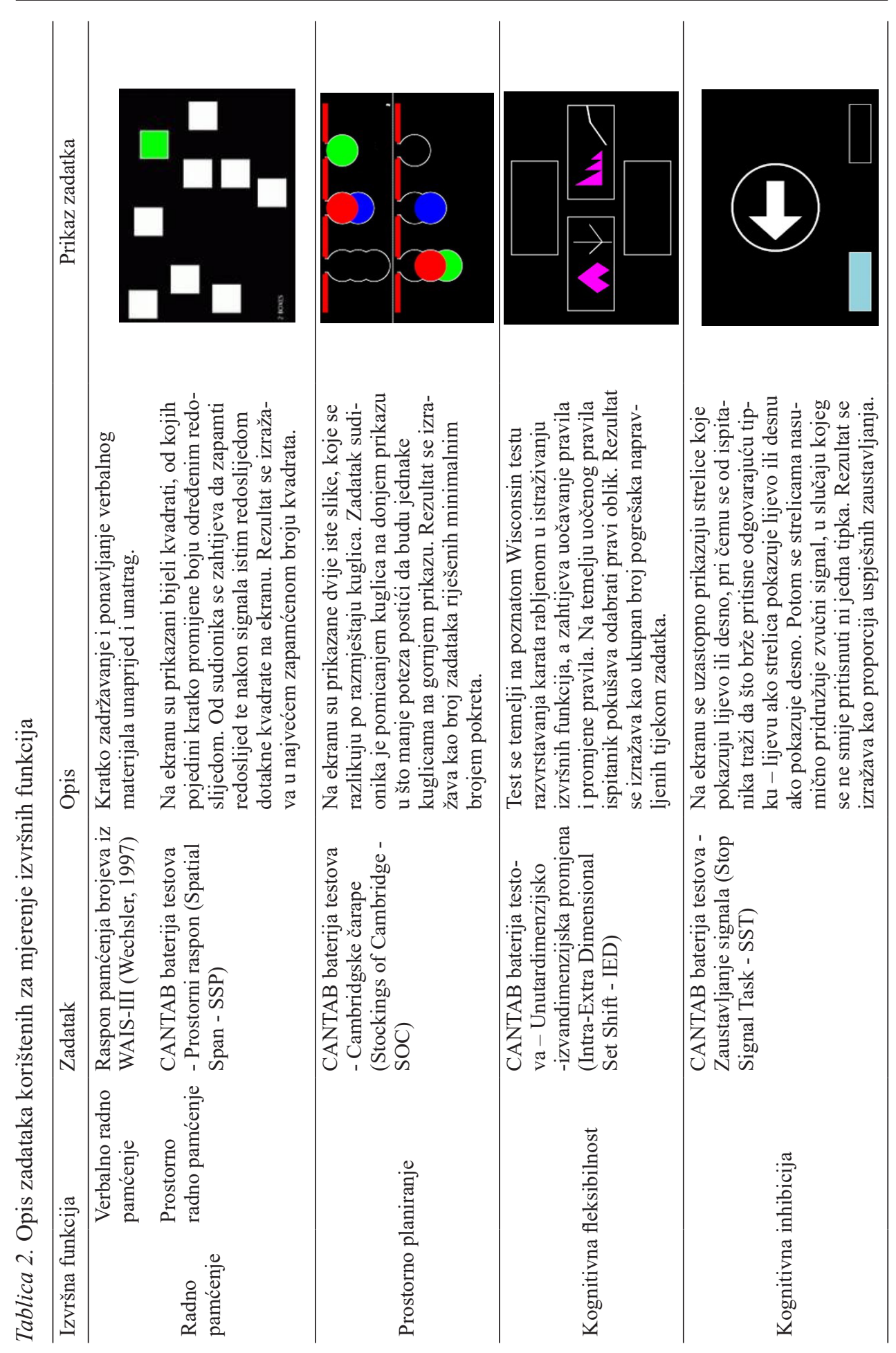

(C) "Naklada Slap", 2017. Sva prava pridržana. 
zadatka kojima se ispituju različite kognitivne funkcije. Primjenjuje se u dobi od 4 do 90 godina. Za potrebe ovog istraživanja odabrana su četiri zadatka koji ispituju izvršne funkcije. Odabrani zadaci opisani su u Tablici 2.

\section{b) Jezični testovi}

Za ispitivanje jezika rabljeni su testovi koji su prilagođeni i normirani za hrvatski jezik. Testom razumijevanja gramatike - druga verzija (TROG-2:HR) (Bishop, Kuvač Kraljević, Hržica i Kologranić Belić, 2003) ispitano je razumijevanje različitih sintaktičkih struktura. Test se sastoji od 80 rečenica (čestica) podijeljenih u 20 različitih rečeničnih struktura. Za potrebe ovog istraživanja rečenične su strukture

Tablica 3. Strukture jednostavnih i složenih rečenica iz TROG-2:HR

\begin{tabular}{|c|c|c|c|}
\hline $\begin{array}{l}\text { Strukture jednostavnih } \\
\text { rečenica (JR) }\end{array}$ & Primjeri JR & $\begin{array}{l}\text { Strukture složenih } \\
\text { rečenica (SR) }\end{array}$ & Primjeri SR \\
\hline Rečenice s dva člana & Šal je žut. & $\begin{array}{l}\text { Izravni anaforički } \\
\text { odnosi }\end{array}$ & $\begin{array}{l}\text { Kutija je u šalici } i \\
\text { plava je. }\end{array}$ \\
\hline Rečenice s negacijom & Vilica nije velika. & $\begin{array}{l}\text { Atributne odnosne } \\
\text { rečenice (subjekt) }\end{array}$ & $\begin{array}{l}\text { Čovjek koji jede, gleda } \\
\text { psa. }\end{array}$ \\
\hline Rečenice s $u$ i $n a$ & Šalica je u cipeli. & $\begin{array}{l}\text { Naknadna izmjena } \\
\text { subjekta }\end{array}$ & Šal na štapu je plav. \\
\hline Glagolski vid & Čovjek je složio kuću. & $\begin{array}{l}\text { Relativna uporaba } \\
\text { prezenta }\end{array}$ & Jest će kad popije. \\
\hline $\begin{array}{l}\text { Rečenice s tri člana } \\
\text { (SPO) }\end{array}$ & Pas stoji na stolu. & $\begin{array}{l}\text { Atributne odnosne } \\
\text { rečenice (objekt) }\end{array}$ & $\begin{array}{l}\text { Dječak dira psa koji } \\
\text { leži. }\end{array}$ \\
\hline Rečenice s četiri člana & $\begin{array}{l}\text { Dječak gleda stolicu } \\
\text { i štap. }\end{array}$ & Umetnute rečenice & $\begin{array}{l}\text { Patka na kojoj je lopta } \\
\text { je žuta. }\end{array}$ \\
\hline $\begin{array}{l}\text { Rečenice s } \\
\text { komparacijom }\end{array}$ & Toranj je viši od zida. & & \\
\hline Rečenice s tri člana & Dječaka gura slon. & & \\
\hline $\begin{array}{l}\text { Zamjenice u jednini i } \\
\text { množini }\end{array}$ & On ih lovi. & & \\
\hline $\begin{array}{l}\text { Rečenice s iznad } \mathrm{i} \\
\text { ispod }\end{array}$ & Cvijet je iznad patke. & & \\
\hline $\begin{array}{l}\text { Rečenice s dvostrukom } \\
\text { negacijom }\end{array}$ & $\begin{array}{l}\text { Ni jedno stablo nema } \\
\text { jabuke. }\end{array}$ & & \\
\hline $\begin{array}{l}\text { S i O u jednini ili } \\
\text { množini }\end{array}$ & Mačka lovi patke. & & \\
\hline $\begin{array}{l}\text { Rečenice s } \\
\text { instrumentalom }\end{array}$ & Žena čisti četkom. & & \\
\hline Označivači količine & $\begin{array}{l}\text { Većina mačaka je } \\
\text { bijela. }\end{array}$ & & \\
\hline
\end{tabular}


podijeljene s obzirom na složenost - jednostavne rečenice i složene rečenice (Tablica 3). Uz svaku izgovorenu rečenicu ispitaniku su prikazane četiri slike među kojima ispitanik treba odabrati onu koja odgovara rečenici koju je ispitivač pročitao. Dakle, tri slike su distraktori, a jedna predstavlja značenje rečenice.

Peabody slikovnim testom rječnika (PPVT-III HR) (Dunn i sur., 2010) ispitan je receptivni rječnik. Test sadrži 17 setova od po 12 riječi (čestica) poredanih po težini, od lakših prema težima. Zadatak je ispitanika odabrati jednu od ponuđene četiri slike koja odgovara značenju riječi koju je ispitivač izrekao. Od četiri ponuđene slike tri predstavljaju distraktora - fonološkog i/ili semantičkog. Primjerice, uz ciljanu riječi pravorijek prikazana su dva fonološka distraktora - rijeka koja teče ravno i propovijed - te jedan semantički distraktor - zatvor.

\section{Postupak}

Sudionici su ispitivani individualno u prostorijama Laboratorija za psiholingvistička istraživanja (POLIN). Ispitivanje je prosječno trajalo između 90 i 120 minuta po ispitaniku. Prije provođenja ispitivanja sudionici su upoznati s istraživanjem te su ispunili pristanak za sudjelovanje u istraživanju. Kako bi se kontrolirali serijalni efekti, dio ispitanika ispitan je prvo jezičnim testovima, a drugi dio prvo testovima za procjenu izvršnih funkcija.

\section{REZULTATI}

U Tablici 4 prikazani su deskriptivni podaci koji opisuju rezultate na ispitanim varijablama izvršnih funkcija te rezultate na jezičnim testovima.

Normalnost distribucije testirana je Shapiro-Wilkovim testom. Rezultati testa pokazali su da distribucija odgovara normalnoj na otprilike polovini varijabli. Varijable prostornog radnog pamćenja, kognitivne fleksibilnosti, kognitivne inhibicije i razumijevanja rečenica odstupale su od normalne distribucije. Međutim, uvidom u obilježja distribucije rezultata, zbog nepostojanja ekstremnih odstupanja u zakrivljenosti i simetričnosti, smatra se opravdanim provoditi parametrijsku statistiku (Petz, 1997).

Kako bi se utvrdila povezanost između prediktorskih varijabli, provedena je korelacijska analiza. Rezultati korelacijske analize upućuju na značajnu povezanost između dvije varijable verbalnog radnog pamćenja $(\mathrm{r}=0,489 ; \mathrm{p}<0,05)$, prostornog radnog pamćenja i planiranja $(\mathrm{r}=0,394 ; \mathrm{p}<0,05)$ te između prostornog planiranja i kognitivne fleksibilnosti $(r=-0,386 ; \mathrm{p}<0,05)$. Interpretacija koeficijenta korelacije upućuje na nisku povezanost, koja samo između varijabli verbalnog radnog pamćenja prelazi u stvarnu značajnu povezanost. Iako zadaci ponavljanja brojeva unaprijed i unatrag mjere različite konstrukte pamćenja, oni su ipak dio verbalnog 
Tablica 4. Deskriptivne vrijednosti za varijable izvršnih funkcija i jezičnog razumijevanja $(N=30)$

\begin{tabular}{|c|c|c|c|c|c|c|c|c|}
\hline & $\mathrm{N}$ & 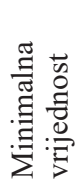 & 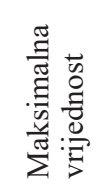 & 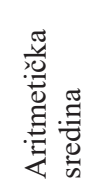 & 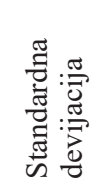 & 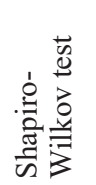 & 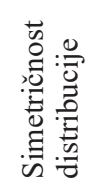 & 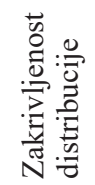 \\
\hline $\begin{array}{l}\text { Verbalno radno pamćenje } \\
\text { - fonološka petlja }\end{array}$ & 30 & 8,00 & 16,00 & 11,90 & 2,074 & 0,093 & $-0,190$ & $-0,198$ \\
\hline $\begin{array}{l}\text { Verbalno radno pamćenje } \\
\text { - središnji izvršitelj }\end{array}$ & 30 & 6,00 & 16,00 & 11,00 & 2,364 & 0,325 & $-0,198$ & $-0,398$ \\
\hline Prostorno radno pamćenje & 30 & 5,00 & 9,00 & 7,00 & 1,365 & 0,001 & $-0,319$ & $-0,982$ \\
\hline Prostorno planiranje & 30 & 6,00 & 12,00 & 8,90 & 1,788 & 0,141 & 0,044 & $-0,821$ \\
\hline Kognitivna fleksibilnost & 30 & 7,00 & 63,00 & 29,23 & 20,458 & 0,000 & 0,535 & $-1,448$ \\
\hline Kognitivna inhibicija & 30 & 0,28 & 0,78 & 0,50 & 0,107 & 0,002 & $-0,112$ & $-0,439$ \\
\hline $\begin{array}{l}\text { Razumijevanje JR } \\
\text { (TROG-2:HR) }\end{array}$ & 30 & 49,00 & 56,00 & 54,50 & 1,700 & 0,000 & $-1,543$ & 1,434 \\
\hline $\begin{array}{l}\text { Razumijevaje SR } \\
\text { (TROG-2:HR) }\end{array}$ & 30 & 19,00 & 24,00 & 22,83 & 1,488 & 0,000 & $-1,244$ & 0,964 \\
\hline $\begin{array}{l}\text { Receptivni rječnik } \\
\text { (PPVT-III-HR) }\end{array}$ & 30 & 87,00 & 134,00 & 103,80 & 10,410 & 0,127 & 0,831 & 0,845 \\
\hline
\end{tabular}

radnog pamćenja, zbog čega je određena razina povezanosti očekivana. Također, postojeći stupnjevi povezanosti među prediktorima nisu dovoljno visoki $(\mathrm{r}<0,8)$ da bi imali utjecaj na provođenje i interpretaciju regresijske analize (Petz, 1997), zbog čega je zadržano svih šest prediktorskih varijabli. Između prediktivnih i kriterijskih varijabli značajna povezanost utvrđena je između razumijevanja složenih rečenica i verbalnog radnog pamćenja $(\mathrm{p}<0,05)$.

Kako bi se odgovorilo na problem ovog istraživanja, odnosno ispitao doprinos izvršnih funkcija u različitim aspektima jezičnog razumijevanja, provedene su linearne regresijske analize u kojima su kriterijske varijable činile tri varijable jezičnog razumijevanja, a prediktorske varijable uspješnost na zadacima izvršnih funkcija odnosno u zadacima inhibicijske kontrole, prostornog radnog pamćenja, prostornog planiranja, kognitivne fleksibilnosti, verbalnog radnog pamćenja - fonološke petlje i središnjeg izvršitelja.

Prvo su ispitane varijable izvršnih funkcija u odnosu s receptivnim rječnikom. Vrijednost multiple korelacije $(\mathrm{R}=0,503)$ nije se pokazala statistički značajnom ( $\mathrm{p}$ $>0,05$ ). Isti rezultat dobiven je i za kriterijsku varijablu razumijevanja jednostavnih rečenica, gdje vrijednost multiple korelacije također nije dosegla statističku značajnost $(\mathrm{R}=0,470 ; \mathrm{p}>0,05)$. $\mathrm{S}$ obzirom na rezultat može se zaključiti da na temelju 


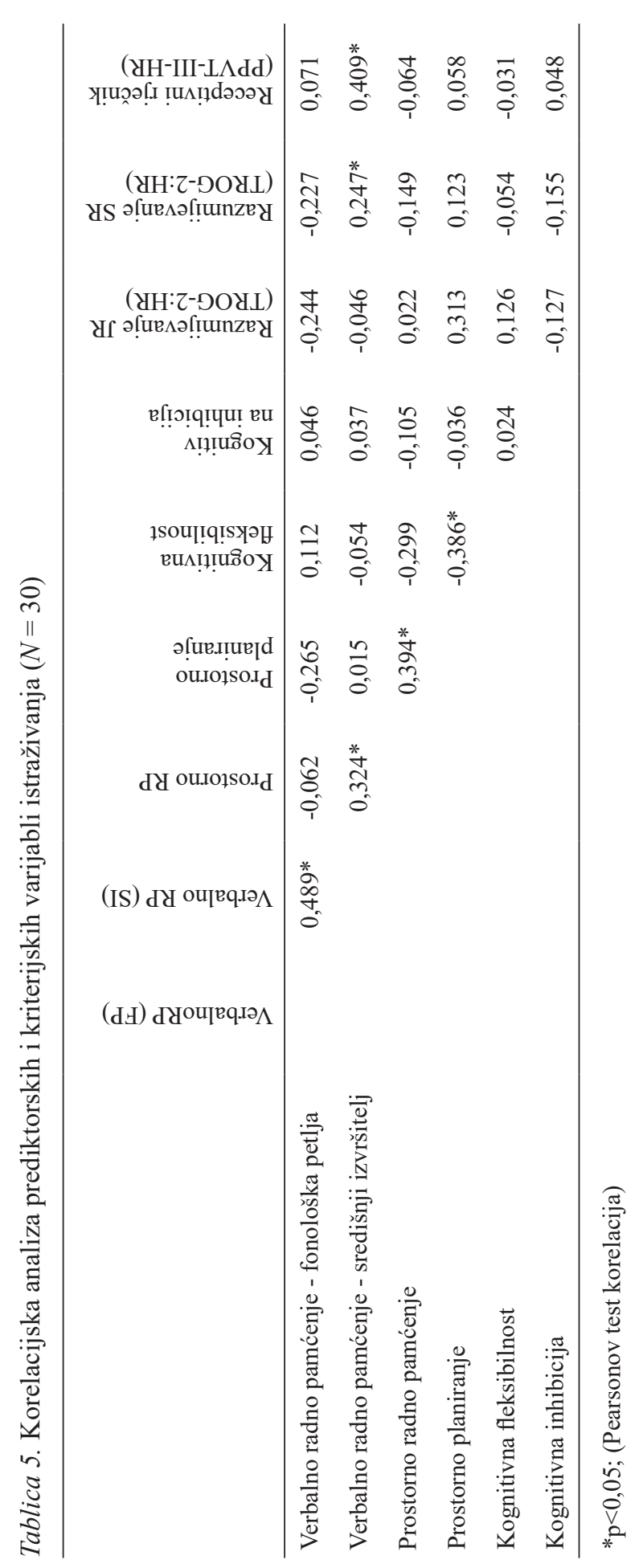

(C) "Naklada Slap", 2017. Sva prava pridržana. 
Tablica 6. Rezultati linearnih regresijskih analiza za tri različite kriterijske varijable $(N=30)$

\begin{tabular}{lccc}
\hline & $\begin{array}{c}\text { Vrijednost multiple } \\
\text { korelacije }(\mathrm{R})\end{array}$ & $\begin{array}{c}\text { Proporcija varijance } \\
\text { kriterija }\left(\mathrm{R}^{2}\right)\end{array}$ & $p$ \\
\hline Razumijevanje JR (TROG-2:HR) & 0,503 & 0,196 & 0,516 \\
Razumijevanje SR (TROG-2:HR) & 0,610 & 0,372 & 0,050 \\
Receptivni rječnik (PPVT-III-HR) & 0,470 & 0,260 & 0,330 \\
\hline
\end{tabular}

Tablica 7. Rezultati linearne regresijske analize za kriterijsku varijablu razumijevanja složenih rečenica

\begin{tabular}{lccc}
\hline & B koeficijent & $\beta$ koeficijent & $p$ \\
\hline Verbalno radno pamćenje - fonološka petlja & $-0,636$ & 0,256 & 0,021 \\
Verbalno radno pamćenje - središnji izvršitelj & 0,784 & 0,592 & 0,001 \\
Prostorno radno pamćenje & $-0,459$ & 0,198 & 0,030 \\
Prostorno planiranje & 0,094 & 0,169 & 0,585 \\
Kognitivna fleksibilnost & $-0,044$ & 0,048 & 0,376 \\
Kognitivna inhibicija & $-6,208$ & 2,821 & 0,390 \\
\hline
\end{tabular}

prediktorskih varijabli nije moguće objasniti varijancu kriterijske varijable receptivnog rječnika ni razumijevanja jednostavnih rečenica.

Treća regresijska analiza provedena je na kriterijskoj varijabli razumijevanja složenih rečenica. Analiza varijance kriterija pokazala je da je u ovom slučaju koeficijent multiple korelacije $(R=0,610)$ statistički značajan $(p<0,05)$, što daje temelj za njegovu daljnju interpretaciju. Na temelju proporcija varijance kriterija $\left(\mathrm{R}^{2}=\right.$ 0,372 ) može se zaključiti da prediktori rabljeni u ovom istraživanju mogu objasniti $37,2 \%$ varijance kriterija. Ipak, vrijednost proporcije varijance kriterija ima tendenciju biti veća nego što je u populaciji te ju je u pravilu potrebno statistički korigirati (Petz, 1997). U ovom slučaju korigirana vrijednost varijance kriterija iznosi 0,208, odnosno 20,8\%. Kako bi se navedeni postotak objasnio, potrebno se osvrnuti na vrijednosti Beta koeficijenata koji, ako su statistički značajni, označavaju važnost pojedinog prediktora u regresijskoj jednadžbi. Prediktorske varijable izvršnih funkcija koje su se pokazale statistički značajnima u regresijskoj jednadžbi s rečeničnim razumijevanjem su dvije varijable verbalnog radnog pamćenja - ponavljanje brojeva unaprijed (fonološka petlja) $(\mathrm{p}<0,05)$, ponavljanje brojeva unatrag (središnji izvršitelj) $(\mathrm{p}<0,01)$ te varijabla prostornog radnog pamćenja $(\mathrm{p}<0,05)$. Ipak, prije konačne interpretacije potrebno je provjeriti korelacije između prediktorskih varijabli i kriterijske varijable koje otkrivaju eventualne supresor varijable - varijable 
koje nisu u korelaciji s kriterijskom varijablom i koje se stoga ne interpretiraju kao prediktivne. U ovom slučaju su se varijable ponavljanja brojeva unaprijed i varijabla prostornog radnog pamćenja pokazale nepovezane s kriterijskom varijablom, zbog čega se isključuju iz daljnje interpretacije te se dalje interpretira samo prediktor ponavljanje brojeva unatrag čiji Beta koeficijent iznosi 0,592.

\section{RASPRAVA}

Pregled istraživanja usmjerenih prema određivanju uloge izvršnih funkcija u procesu jezičnog razumijevanja navodi na oprečne zaključke. Iako rijetko, postoje nalazi prema kojima izvršne funkcije nisu uključene u obradu rečenica, kako jednostavnih, tako ni složenih (Kuperberg, 2007). Prema tim istraživanjima, čak i u lingvistički konfliktnim situacijama tumačenje rečenica odvija se isključivo unutar jezičnog sustava te prednost nad nesintaktičkim procesima uvijek imaju sintaktički procesi.

S druge pak strane, povezanost izvršnih funkcija sa složenim rečenicama dokazana je više puta (Yoon i sur., 2015), čime se upućuje na suptilnu ulogu izvršnih funkcija u rečeničnom razumijevanju koja u odraslih govornika urednog neurološkog statusa dolazi do izražaja tek u obradi sintaktički zahtjevnijih rečenica (Van Gompel i Pickering, 2007).

Rezultati ovog istraživanja idu u prilog upravo potonjim istraživanjima. Naime, regresijska analiza pokazala je da varijable izvršnih funkcija u ranoj odrasloj dobi nisu dobar prediktor varijance kriterijskih varijabli receptivnog rječnika niti razumijevanja jednostavnih rečenica. Nadalje, samo jedna od šest varijabli izvršnih funkcija pokazala se prediktivnom, čime se hipoteza - da su varijable izvršnih funkcija dobar prediktor rezultata razumijevanja složenih rečenica - može smatrati djelomično prihvaćenom.

Prediktivnom varijablom u ovome se slučaju pokazao zadatak pamćenja brojeva unatrag koji aktivira verbalno radno pamćenje. Negativni predznak $\beta$ koeficijenta za varijable ponavljanja brojeva unaprijed i prostornog radnog pamćenja odražava supresorsko djelovanje spomenutih varijabli. Prema Cohenu i Cohenu (1975), supresor je varijabla koja nije u korelaciji s kriterijem, a ipak doprinosi objašnjenju varijance kriterijske varijable jer je povezana s jednim ili više prediktora, u ovom slučaju s varijablom ponavljanje brojeva unatrag iz kojih uklanja tzv. varijancu pogreške.

Ako se osvrnemo na prediktivnu varijablu pamćenja brojeva unatrag, prema Baddeleyevu modelu (Gathercole i Baddeley, 1993) radi se o središnjem izvršitelju, nadređenoj sastavnici radnog pamćenja, koji prebacuje pažnju, potiskuje manje važne informacije sprječavajući njihovo ometanje djelovanja radnog pamćenja i obnavlja njegov sadržaj otpuštajući informacije koje više nisu relevantne. Radno pamćenje najistraživanija je sastavnica izvršnih funkcija te se u velikom broju 
istraživanja pokazala povezanom s obradom rečenica (Fengler, Meyer i Friederici, 2015; Martin i sur., 2007). Većina slučajeva u kojima se pokazalo povezanim, bili su upravo slučajevi sintaktički ili semantički složenih ili dvosmislenih rečenica koje su zahtjevnije za obradu. Takve rečenice zbog svoje složenosti očito zahtijevaju aktivaciju radnog pamćenja kao potpore njihovoj obradi, što je pokazalo i ovo istraživanje.

O značajnosti veze radnog pamćenja i razumijevanja složenih rečenica u ovom istraživanju dodatno govori činjenica da se efekt uspio pokazati bez obzira na mali uzorak te vrstu složenih rečenica koje nisu uključivale sintaktičku ni semantičku dvosmislenost. Dobiveni rezultat ide u prilog teoriji o paralelnom rečeničnom procesiranju, prema kojem se pri analiziranju složenih rečeničnih struktura stvaraju višestruke reprezentacije svih mogućih rečeničnih značenja, koje se zadržavaju i uspoređuju te se odabire najvjerojatnija interpretacija (Novais-Santos i sur., 2007). Pri tome je uloga radnog pamćenja upravo zadržati informacije i tako ih činiti stalno dostupnima kako bi se paralelno provodilo ispitivanje njihova međuodnosa kombiniranjem pojedinih elemenata (Diamond i Ling, 2016).

Također, rezultati ovog istraživanja, u kojem do aktivacije pojedinih izvršnih funkcija dolazi tek pri obradi gramatički složenijih, a time i kognitivno zahtjevnijih rečenica, u skladu su s novijim istraživanjima koja i na izvršne funkcije i na jezik gledaju kao na neuralnu mrežu (Fedorenko i Thompson-Schill, 2014; Ye i Zhou, 2009). Prema takvom shvaćanju, jezik kao specifična kognitivna domena i izvršne funkcije kao općenita u slučajevima se složenijih jezičnih zadataka preklapaju i zajedno surađuju, pri čemu se predlažu i nazivi "jezgrenih procesa" za specifične, jezične, procese te "perifernih procesa" za one općenite, koji se odnose na izvršne funkcije i uključuju prema potrebi. Takav model rečenične obrade, koji pretpostavlja postojanje jezgre koju čine sintaktički procesi i izvršnih funkcija koje prema potrebi podupiru procese jezgre, opisuje i Friederici (2002), nazivajući ga dvokomponentnim modelom jezične obrade.

\section{Nedostaci istraživanja i smjernice za buduća istraživanja}

Osim malim brojem ispitanika, nepovezanost nekih varijabli može se objasniti razinom složenosti rečenica. Iako je test TROG-HR:2 konstruiran tako da kroz ponuđene slične odgovore smanjuje mogućnost oslanjanja na zaključivanje eliminacijom te zahtijeva preciznu obradu rečenice, moguće je da složene rečenice nisu dovoljno zahtjevne da bi potaknule aktivaciju ostalih izvršnih funkcija, koje su možda manje izražene u obradi od verbalnog radnog pamćenja. Promotre li se druga istraživanja (primjerice, Van Gompel i Pickering, 2007) pokazalo se da se efekti utjecaja izvršnih funkcija u rečeničnoj obradi odrasle populacije dobivaju većinom tek na sintaktički i/ili semantički dvosmislenim rečenicama koje su po svojoj strukturi ipak zahtjevnije za obradu od rečenica obuhvaćenih TROG-HR:2. 
U literaturi se često postavlja i pitanje primjerenosti zadataka za procjenu izvršnih funkcija (Chan i sur., 2008; Friedman i sur., 2008; Jurado i Rosselli, 2007) za koje ne postoji zlatni standard (Chan i sur., 2008). Teškoće u definiranju izvršnih funkcija i prisutnost različitih modela otežava razvijanje i usuglašavanje oko pojedinih testova (Jurado i Rosselli, 2007). Uz to, problem je što se one po svojoj prirodi manifestiraju tako da upravljaju i drugim kognitivnim procesima, zbog čega je teško pronaći zadatak koji bi procjenjivao samo jednu sastavnicu izvršnih funkcija bez utjecaja drugih kognitivnih procesa (Miyake i sur., 2000).

S obzirom na postojeće rezultate, temu povezanosti izvršnih funkcija i jezika potrebno je dodatno istražiti. Imajući u vidu rezultate ovog istraživanja koji govore o vezi između izvršnih funkcija i složenih rečenica u odrasloj dobi, sljedeći korak bi mogao biti detaljnije objašnjavanje veze sa složenim rečenicama. Primjerice, utječe li variranje vrste i razine složenosti rečenica na povezanost s izvršnim funkcijama. Strana istraživanja često obuhvaćaju sintaktički ili semantički dvosmislene rečenice, rečenice s većim brojem argumenata i/ili negacija (Yoon i sur., 2015; Fengler i sur., 2015). Stoga bi bilo zanimljivo vidjeti na koji se način obrada pojedinih navedenih skupina rečenica može povezati s kojim izvršnim funkcijama u hrvatskom jeziku, s obzirom na to da su međujezična istraživanja pokazala da postoji razlika u vrsti složenih rečenica koje aktiviraju izvršne funkcije u odnosu na tipologiju jezika (Bornkessel-Schlesewsky i Friederici, 2007). Osim toga, zbog dostupnosti testova prilagođenih hrvatskom jeziku u ovom su istraživanju ispitane samo mjere receptivnog jezika. Dosadašnja inozemna istraživanja potvrdila su i povezanost izvršnih funkcija s jezičnom proizvodnjom (Sikora, Roelofs, Hermans i Knoors, 2016), zbog čega bi u budućim istraživanjima bilo dobro obuhvatiti i taj jezični aspekt te dobivene rezultate usporediti s onima dobivenim u ispitivanju povezanosti izvršnih funkcija i jezičnog razumijevanje. Zbog istraživanja koja govore kako je povezanost izvršnih funkcija i jezika pod snažnim utjecajem dobi (Yoon i sur., 2015), važno je također prikupiti informacije o njihovoj povezanosti u različitim dobnim skupinama. Bez obzira što je veza istaknutija tijekom djetinjstva dok se izvršne funkcije i jezik još uvijek razvijaju (Choi i Trueswell, 2010), ili tijekom starosti, kada već počinju opadati (Park, 2015), važno je ne zanemariti ni ranu i srednju odraslu dob kada su obje funkcije najstabilnije.

\section{ZAKLJUČAK}

Na visoku povezanost izvršnih funkcija i jezika, osobito gledano iz evolucijske i razvojne perspektive, upućuju mnogi znanstveni radovi (Adornetti, 2016; Ardila, 2008; Gooch i sur., 2016). Ipak, dok je međudjelovanje izvršnih funkcija i jezika jasnije izraženo tijekom djetinjstva, njihov odnos teže je objasniti u odrasloj dobi, kada su oba sustava razvijenija. Stoga je cilj ovog istraživanja bio utvrditi vezu između receptivnog jezika i izvršnih funkcija u odrasloj dobi proučavanjem dopri- 
nosa pojedinih izvršnih funkcija u obradi na razini leksičke i sintaktičke sastavnice. Rezultati su pokazali da ne postoji povezanost izvršnih funkcija i rječničkog razumijevanja, ali da postoji veza izvršnih funkcija s rečeničnim razumijevanjem. Ipak, povezanost izvršnih funkcija s rečeničnim razumijevanjem određena je složenošću rečenica. Dok kod obrade jednostavnih rečenica povezanost s izvršnim funkcijama nije utvrđena, s obradom složenih rečenica povezanom se pokazala izvršna funkcija radnog pamćenja.

Daljnji koraci u istraživanju tog odnosa trebali bi obuhvatiti i druge specifične vrste složenih rečenica kako u razumijevanju tako i u proizvodnji, kako bi se preciznije objasnila uloga izvršnih funkcija u jezičnoj obradi odraslih, a time i općenito produbila spoznaja o međuodnosu izvršnih funkcija i jezika.

\section{LITERATURA}

Adornetti, I. (2016). On the phylogenesis of executive functions and their connection with language evolution. Frontiers in Psychology, 7, 1-4.

Ardila, A. (2008). On the evolutionary origins of executive functions. Brain and Cognition, $68,92-99$.

Bishop, D.V.M., Kuvač Kraljević, J., Hržica, G., Kovačević M. i Kologranić Belić, L. (2003). Test razumijevanja gramatike - TROG-2:HR. Jastrebarsko: Naklada Slap.

Bornkessel-Schlesewsky, I.D. i Friederici, A.D. (2007). Neuroimaging studies of sentence and discourse comprehension. U M.G. Gaskell (Ur.), The Oxford Handbook of Psycholinguistics, (str. 407-424). Oxford: University Press.

Burgess, P. W. i Simons, J. S. (2005). Theories of frontal lobe executive function: clinical applications. In P. W. Halligan \& D. T. Wade (Eds.), Effectiveness of Rehabilitation for Cognitive Deficits (str. 211-31). New York: Oxford Univ. Press.

Cambridge Cognition. CANTAB Computerized Cognitive Assessments. Preuzeto s http:// www.cambridgecognition.

Chan, R.C.K., Shumb, D., Toulopoulou, T. i Chen, E.Y.H. (2008). Assessment of executive functions: Review of instruments and identification of critical issues. Archives of Clinical Neuropsychology, 23, 201-216.

Choi, Y. i Trueswell, J.C. (2010). Children's (in)ability to recover from garden-paths in a verb-final language: Evidence for developing control in sentence processing. Journal of Experimental Child Psychology, 106, 41-61.

Cohen, J. i Cohen, P. (1975). Applied multiple regression / correlation analysts for the behavioral sciences. New York: Wiley.

Diamond, A. i Ling, D.S. (2016). Conclusions about interventions, programs, and approaches for improving executive functions that appear justified and those that, despite much hype, do not. Developmental Cognitive Neuroscience, 18, 34-48.

Dunn, L. M., Dunn, L.M., Kovačević, M., Padovan, N., Hržica, G., Kuvač Kraljević, J., Mustapić, M., Dobravac, G. i Palmović, M. (2010). Peabody slikovni test rječnika, PPVT-III-HR. Jastrebarsko: Naklada Slap. 
Espy, K. A. (2004). Using developmental, cognitive, and neuroscience approaches to understand executive control in young children. Developmental neuropsychology, 26, 379384.

Fedorenko, E. i Thompson-Schill, S.L. (2014) Reworking the language network. Trends in Cognitive Sciences, 18, 120-126.

Fengler, A., Meyer, L. i Friederici, A.D. (2015). Brain structural correlates of complex sentence comprehensionin children. Developmental Cognitive Neuroscience, 15, 48-57.

Fox, M.C., Berry, J.M. i Freeman, S.P. (2014). Are vocabulary tests measurement invariant between age groups? An item response analysis of three popular tests. Psychology and Aging, 29, 925-938.

Friederici, A.D. (2002). Towards a neural basis of auditory sentence processing. Trends in Cognitive Sciences 6, 78-84.

Friedman, N.P., Miyake, A., Young, S.E., DeFries, J.C., Corley, R.P. i Hewitt, J.K. (2008). Individual differences in executive functions are almost entirely genetic in origin. Journal of Experimental Psychology: General, 137, 201-225.

Gathercole, S.E. (2007). Working memory and language. U M.G. Gaskell (Ur.), The Oxford Handbook of Psycholinguistics, (str. 757-770). Oxford: University Press.

Gathercole, S.E. i Baddeley, E.D. (1993). Working memory and language. Hove: Psychology Press.

Gooch, D., Thompson, P., Nash, H.M., Snowling, M.J. i Hulme, C. (2016). The development of executive function and language skills in the early school years. Journal of Child Psychology and Psychiatry, 57, 180-187.

Harley, T. (2001). The psychology of language. Hove: Psychology Press.

Huizinga, M., Dolan, C.V. i van der Molen, W.S. (2006). Age-related change in executive function: Developmental trends and a latent variable analysis. Neuropsychologia, 44, 2017-2036.

Jurado, M.B. i Rosselli, M. (2007). The elusive nature of executive functions: A review of our current understanding. Neuropsychology Review, 17, 213-233.

Kapa, L.L. (2013). Executive function predicts artificial language learning in children and adults. (Neobjavljena doktorska disertacija). Lawrence: Child Language, University of Kansas.

Kuperberg, G. R. (2007). Neural mechanisms of language comprehension: Challenges to syntax. Brain research, 1146, 23-49.

Martin, R.C., Vuong, L.C. i Crowther, J.E. (2007). Sentence-level deficits in aphasia. U M.G. Gaskell (Ur.), The Oxford Handbook of Psycholinguistics, (str. 425-441). Oxford: University Press.

Miyake, A., Friedman, N.P., Emerson, M.J., Witzki, A.H., Howerter, A. i Wager, T.D. (2000). Contributions to complex "Frontal lobe" tasks: A latent variable analysis. Cognitive Psychology, 41, 49-100.

Novais-Santos, S., Gee, J., Shah, M., Troiani, V., Work, M., i Grossman, M. (2007). Resolving sentence ambiguity with planning and working memory resources: Evidence from fMRI. Neuroimage, 37, 361-378.

Petz, B. (1997). Osnovne statističke metode za nematematičare. Slap, Zagreb. 
Park, Y. (2015). Roles of shifting attention, alternating attention and inhibition on temporary syntactic ambiguity resolution and use of context in younger and older adults. (neobjavljena doktorska disertacija). New York: Speech-Language-Hearing Sciences, City University of New York.

Raven, J. C., (1995). Progresivne matrice u boji - CPM. Jastrebarsko: Naklada Slap.

Sikora, K., Roelofs, A., Hermans D. i Knoors, H. (2016). Executive control in spoken nounphrase production: Contributions of updating, inhibiting, and shifting. The Quarterly Journal of Experimental Psychology, 69, 1719-1740.

Šimleša, S. (2013). Međuodnos izvršnih funkcija, teorije uma i jezičnog razumijevanja u djece predškolske dobi. (Neobjavljena doktorska disertacija). Zagreb: Filozofski fakultet, Sveučilište u Zagrebu.

Van Gompel, R.P.G i Pickering, M.J. (2007). Syntactic parsing. U M.G. Gaskell (Ur.), The Oxford Handbook of Psycholinguistics, (str. 289-308). Oxford: University Press.

Veroude, K., Jolles, J., Croiset, G. i Krabbendam, L. (2013). Changes in neural mechanisms of cognitive control during the transition from late adolescence to young adulthood. Developmental Cognitive Neuroscience, 5, 63-70.

Vuong, L.C. i Martin, R.C. (2015). The role of LIFG-based executive control in sentence comprehension. Cognitive Neuropsychology, 32, 243-265.

Wechsler, D. (1997). WAIS-III administration and scoring manual. San Antonio, TX: The Psychological Corporation.

Weiland, C., Barata, M.C. i Yoshikawa, H. (2014). The co-occurring development of executive function skills and receptive vocabulary in preschool-aged children: A look at the direction of the developmental pathways. Infant and Child Development, 23, 4-21.

Xu F., Han Y., Sabbagh M.A., Wang T., Ren X. i Li, C. (2013). Developmental differences in the structure of executive function in middle childhood and adolescence. PLoS ONE, 8, e 77770 .

Ye, Z. i Zhou, X. (2009). Executive control in language processing. Neuroscience and Biobehavioral Reviews, 33, 1168-1177.

Yoon, J., Campanelli, L., Goral, M., Marton, K., Eichorn, N. i Obler, L.K. (2015). The effect of plausibility on sentence comprehension among older adults and its relation to cognitive functions. Experimental Aging Research, 41, 272-302.

\title{
RELATIONSHIP BETWEEN EXECUTIVE FUNCTIONS AND LANGUAGE IN ADULTHOOD
}

\begin{abstract}
Numerous studies provide evidence of the relationship between executive functions and language. However, due to the complexity of executive functions and difficulties in defining and measuring them, this relationship is still not clear enough. The majority of executive functions research is based on studying child language deve-
\end{abstract}


lopment or language development in special populations. Because of the dynamic nature of language and executive functions, which change significantly throughout the lifespan, exploring their interactions in adulthood would contribute to a better and more complete understanding of their relationship. With that in mind, the objective of this study was to examine the relationship between specific components of executive functioning and receptive language skills in adult age. The participants in the study were healthy adults $(\mathrm{N}=30)$, between 21 and 37 years old. Executive functioning components of spatial working memory, planning, cognitive flexibility and cognitive inhibition were assessed with the CANTAB battery of tests, whereas verbal working memory was tested with a subtest of the WISC-III test, the Memory for Digit Span. Peabody Picture Vocabulary Test (PPVT-III-HR) and Test for Reception of Grammar (TROG-2:HR) were administered to assess language skills. The results of the regression analysis indicate a contribution of executive functions to the comprehension of complex sentences but not to the comprehension of simple sentences and receptive vocabulary. These results suggest that the involvement of executive functions in language processing in adults is required only in the comprehension of complex sentences that put a greater demand on language processing. This finding is in agreement with similar conducted research. However, in order to draw a final conclusion on this topic, it is necessary to include older age groups, as well as a larger number of sentences with different levels of syntactic complexity.

Key words: executive functions, language, receptive vocabulary, sentence comprehension, adulthood 
